\title{
Induction of Cytotoxicity through Photo-release of Aminoferrocene
}

Leonidova, Anna ; Anstaett, Philipp ; Pierroz, Vanessa ; Spingler, Bernhard ; Ferrari, Stefano ; Gasser, Gilles

DOI: https://doi.org/10.1021/acs.inorgchem.5b01332

Posted at the Zurich Open Repository and Archive, University of Zurich ZORA URL: https://doi.org/10.5167/uzh-114194

Journal Article

Accepted Version

Originally published at:

Leonidova, Anna; Anstaett, Philipp; Pierroz, Vanessa; Spingler, Bernhard; Ferrari, Stefano; Gasser, Gilles (2015). Induction of Cytotoxicity through Photo-release of Aminoferrocene. Inorganic Chemistry, 54:9740-9748.

DOI: https://doi.org/10.1021/acs.inorgchem.5b01332 


\section{Induction of Cytotoxicity Through Photo-Release of Aminoferrocene}

Anna Leonidova, ${ }^{a, \S}$ Philipp Anstaett, ${ }^{a, \S}$ Vanessa Pierroz, ${ }^{a, b}$ Cristina Mari, ${ }^{a}$ Bernhard Spingler, ${ }^{a}$ Stefano Ferrari ${ }^{b}$ and Gilles Gasser ${ }^{a *}$

a Department of Chemistry, University of Zurich, Winterthurerstrasse 190, CH-8057 Zurich, Switzerland.

${ }^{b}$ Institute of Molecular Cancer Research, University of Zurich, Winterthurerstrasse 190, CH8057 Zurich, Switzerland.

$\S$ These authors have contributed equally to the work.

* Corresponding author: e-mail: gilles.gasser@chem.uzh.ch; Fax: +41 4463546 02;

Tel: +41 4463546 30; homepage: http://www.gassergroup.com. 


\begin{abstract}
Reactive oxygen species (ROS)-activated aminoferrocene-based anticancer prodrug candidates successfully take advantage of intrinsically high amounts of ROS in tumor tissues. Interestingly, the ROS-initiated activation of these prodrug candidates leads to formation of unstable aminoferrocene $\left(\mathbf{F c}-\mathbf{N H}_{2}\right)$ derivatives, which decay to iron ions. The latter catalytically increase ROS concentration to a lethal level. In this work, we prepared light-controlled aminoferrocene prodrug candidates by derivatizing $\mathbf{F c}-\mathbf{N H}_{2}$ with an $\mathbf{O}-$ nitrophenyl and an o-nitrobiphenyl photo-labile protecting group (PLPG), respectively, and by further conjugation to a mitochondria localization signal (MLS) peptide (Cys-D-Arg-PheLys- $\mathrm{NH}_{2}$ ). The resulting bioconjugates were found to be more stable and less cytotoxic, in the dark, towards human promyelocytic leukemia cells (HL-60) compared to $\mathbf{F c}-\mathbf{N H}_{2}$. Upon light irradiation at $355 \mathrm{~nm}$, both conjugates released $\mathbf{F c}-\mathbf{N H}_{\mathbf{2}}$, albeit with very different photolysis quantum yields. The o-nitrobiphenyl photo-cage was in fact several orders of magnitude more efficient than the o-nitrophenyl photo-cage in releasing $\mathbf{F c}-\mathbf{N H}_{\mathbf{2}}$. This difference was reflected by the light irradiation experiments on HL-60 cell line, in which aminoferrocene conjugated with the o-nitrobiphenyl cage and the MLS displayed the highest phototoxicity index $(2.5 \pm 0.4)$ of all the compounds tested. The iron release assays confirmed the rise in iron ions concentrations upon light irradiation of both caged aminoferrocene derivatives. Together with the absence of phototoxicity on the non-malignant hTERT-immortalized retinal pigment epithelial (hTERT RPE-1) cell line, these results indicate catalytic generation of ROS as possible mode of action.
\end{abstract}




\section{Introduction}

Aminoferrocene-based anticancer prodrug candidates recently developed by the Mokhir group have shown considerable selectivity towards cancer cells with $\mathrm{IC}_{50}$ values in the lower micromolar range (see Scheme $1 \mathrm{~A}$ ). ${ }^{1,2}$ These prodrug candidates are activated by reactive oxygen species (ROS) such as ${ }^{1} \mathrm{O}_{2}, \mathrm{O}_{2}{ }^{-}, \mathrm{HO}^{\circ}$ and $\mathrm{H}_{2} \mathrm{O}_{2}$, which cleave the $\mathrm{B}-\mathrm{C}$ bond in an arylboronic acid pinacol ester linked to an aminoferrocene derivative via a carbamate function (see Scheme 1 for mode of action). In water, the resulting phenol is in equilibrium with its phenolate form, which spontaneously fragments into $p$-quinone methide and a carbamated aminoferrocene derivative via 1,6-elimination. The quinone methide is a known toxic compound that readily reacts with nucleophiles and attacks antioxidative defenses of cells by alkylating in particular glutathione (Scheme 1, Mechanism 1). ${ }^{3}$ Indeed, also hydroxyferrocifen - a very efficient anti-cancer drug candidate developed by the Jaouen group - is oxidized to quinone methide metabolites. ${ }^{4}$ Mokhir's aminoferrocene-based prodrug candidates possess, however, an additional mode of action (Scheme 1, Mechanism 2). The latter is mediated by the carbamated aminoferrocene fragment, which decarboxylates under physiological conditions. ${ }^{1,2}$ Most aminoferrocene derivatives are rather unstable since they are easily oxidized to their ferrocenium forms $\left(\mathrm{Fc}^{+}\right),{ }^{5}$ which in turn can decompose into iron ions and cyclopentadiene ligands. ${ }^{1}$ The reason behind the instability of aminoferrocene $\left(\mathbf{F c}-\mathrm{NH}_{2}\right)$ or its ferrocenium form $\left[\mathrm{FcNH}_{2}\right]^{+}$is still speculative. Both $\mathrm{Fc}^{+}$and iron ions can catalyze ROS generation elevating cellular levels of ROS to a toxic level. ${ }^{6,1}$ Tumors generally function at a higher basal concentration of ROS than normal tissues ${ }^{7}$ and are already harmed by relatively small increases in ROS amount. As Mokhir's aminoferrocene-based prodrug candidates are activated by ROS-induced fragmentation, these prodrug candidates are predominantly harming cancer cells. ${ }^{1,2}$ As a matter of fact, the most toxic prodrug candidate of the series has shown more than a 10 -fold selectivity for human promyelocytic leukemia cell line (HL-60) over normal fibroblasts. ${ }^{1}$ Interestingly, the cytotoxicity of the aminoferrocene-based prodrug candidates correlates with their efficiency of ROS production in cells, showing that the aminoferrocene moiety heavily contributes to the observed cytotoxicity. ${ }^{1,2}$ A similar concept has also been implemented by the Jacob group using ROS-activated organochalcogen compounds catalyzing ROS generation. ${ }^{8}$

Besides internal triggers such as high ROS levels, external triggers, e.g. light-activation, can be used to control the activity of a compound. Photosensitizers - molecules able to generate toxic singlet oxygen and other ROS upon light irradiation - are already being applied in the clinic in photodynamic therapy (PDT). ${ }^{9} \mathrm{~A}$ great number of organic photo-active compounds 
A

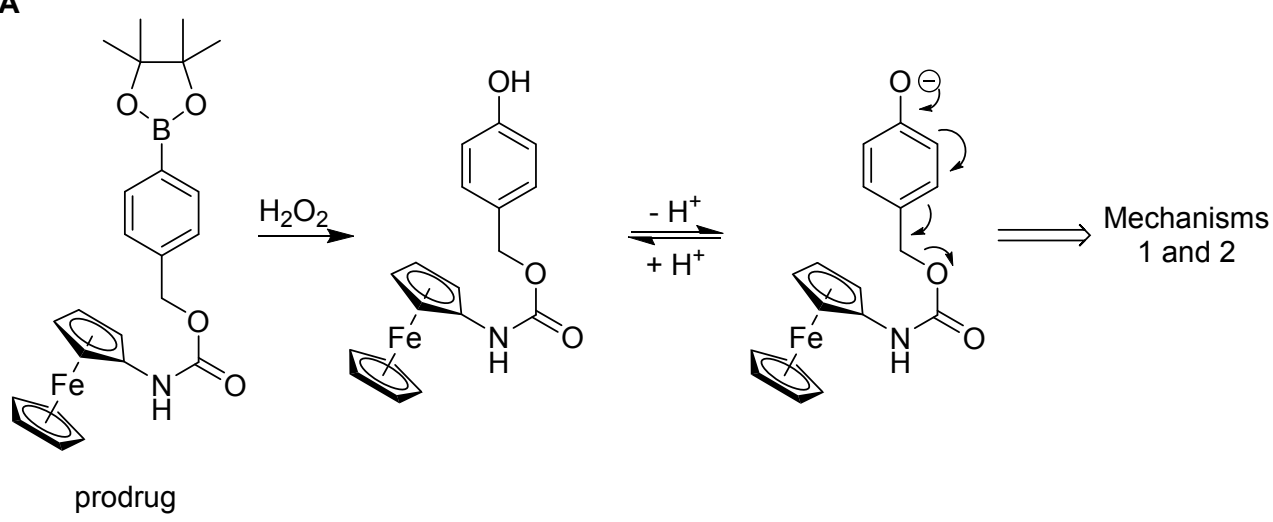

B

Mechanism 1<smiles>C=C=CC(=C)C=CC=O</smiles>

Reaction with nucleophiles (including glutathione)

Mechanism 2
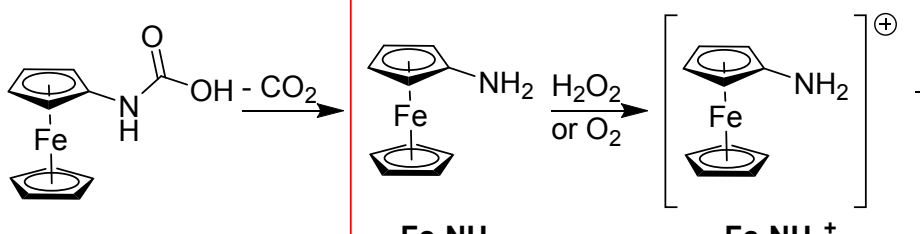

Fc- $\mathrm{NH}_{2}^{+}$

ROS generation catalysts

$\Uparrow$

Fc- $\mathrm{NH}_{2}$

Mechanism used in this study

Scheme 1. A) Activation of a previously reported aminoferrocene-based prodrug candidate by ROS. B) Mechanisms of cytotoxicity.

that are activated via cleavage of a light-sensitive bond have been reported. ${ }^{10,11}$ When it comes to metal complexes, some of them are inherently photo-reactive by themselves via light-induced redox and/or ligand exchange reactions. These changes can be exploited to increase the cytotoxicity of metal compounds ${ }^{12}$ or to construct metal-based photo-cages (e.g. for neurotransmitters).$^{13}$ Encouraged by the recent use of organic photo-cages in the design of light-activated metal-containing prodrug candidates, ${ }^{14,15}$ we envisaged photocaging a simple cytotoxic ferrocenyl derivative, namely $\mathbf{F c}-\mathbf{N H}_{2}$ with $\mathbf{o}$-nitrophenyl-based and o-nitrobiphenyl-based photo-labile protecting groups (PLPG) via a carbamate bond (Scheme 2). The resulting derivatives were expected to be more stable in physiological conditions compared to aminoferrocene itself due to the electron-withdrawing effect of the carbamate. The aminoferrocene would then be liberated upon UV-A light irradiation and oxidized to its ferrocenium form and irons ions, which could act as ROS-generation catalysts in cancer cells. Furthermore, a mitochondrial localization signal (MLS) peptide (Cys-D-Arg-Phe-Lys$\mathrm{NH}_{2}$ ) was added to the photo-caged aminoferrocene bioconjugate to target mitochondria - 
organelles where the redox balance plays an especially important role. ${ }^{16}$ Of note, the conjugation of photocages with targeting peptides has been realized before. ${ }^{15}$

\section{Results and discussion}

\section{Synthesis and Characterization}

Aminoferrocene $\left(\mathbf{F c}-\mathrm{NH}_{2}\right)$ was caged with an o-nitrophenyl-based photo-linker also known as the Dmochowski photo-labile protecting group $1 .^{17}$ Interestingly, this PLPG allows for coupling to a further moiety such as a targeting biomolecule. Our group has previously reported the preparation of PLPG-containing bioconjugates of a rhenium(I) complex ${ }^{18}$ and $\mathrm{Ru}(\mathrm{II})$ complexes. ${ }^{19}$ This coupling procedure could be successfully applied to the photocaging and bioconjugation of $\mathbf{F c}-\mathbf{N H}_{2}$. Following this synthetic protocol, the primary amino group of $\mathbf{F c}-\mathbf{N H}_{2}$ was blocked with $\mathbf{1}$ via $\mathrm{N}$-hydroxysuccinimide ester coupling to give $\mathbf{2}$ (Scheme 2 A). The product was fully characterized by ${ }^{1} \mathrm{H}$ - and ${ }^{13} \mathrm{C}-\mathrm{NMR}$, ESI-MS, LC-MS and X-ray crystallography (see $X$-ray crystallography section). The ESI-MS spectrum (Figure S1) showed the expected mass at $m / z=503.3\left[\mathrm{M}^{+}\right]$. In the ${ }^{1} \mathrm{H}-\mathrm{NMR}$ of 2 , the most notable 
A<smiles>CC(OC(=O)ON1C(=O)CCC1=O)c1cc(CN2C(=O)C=CC2=O)ccc1[N+](=O)[O-]</smiles>

1<smiles>CC(OC(=O)Nc1ccccc1)c1cc(CN2C(=O)C=CC2=O)ccc1[N+](=O)[O-]</smiles>

2<smiles>CC(OC(=O)NC1C=CC=C(c2ccccc2)C1)c1cc(CN2C(=O)CC(S(C)(=O)=O)C2=O)ccc1[N+](=O)[O-]</smiles>

5

B<smiles>CCOc1ccc(-c2ccc([N+](=O)[O-])c(C(C)CO)c2)cc1</smiles>

3<smiles>CCC(C)(C)OCCN1C(=O)C=CC1=O</smiles>

4<smiles>CCOc1ccc(-c2ccc([N+](=O)[O-])c(C(C)COC(=O)Nc3ccccc3F)c2)cc1</smiles>

6

MLS = Cys-D-Arg-Phe-Lys- $\mathrm{NH}_{2}$

Scheme 2. A) Synthesis of 5: a) $\mathbf{F c}-\mathbf{N H}_{2}$, DIPEA, $\mathrm{CHCl}_{3}, 62 \%$; b) Cys-D-Arg-Phe-Lys-NH $\mathrm{H}_{2}$, acetonitrile/water 1:1. B) Synthesis of 6: a) i. N,N'-disuccinimidyl carbonate, triethylamine, acetonitrile; ii. Fc- $\mathbf{N H}_{2}$, DIPEA, $\mathrm{CH}_{2} \mathrm{Cl}_{2}, 50 \%$ over both steps; b) Cys-D-Arg-Phe-Lys- $\mathrm{NH}_{2}$, acetonitrile/PBS $(\mathrm{pH}=7.4) 2: 1$. DIPEA: diisopropylethylamine.

change in shifts compared to the starting materials $\mathbf{F c}-\mathbf{N H}_{2}$ and $\mathbf{1}$ was observed for the aminoferrocene moiety (Figures S3 and S6). Indeed, both the amino group proton - now part of the carbamate bond - and the substituted cyclopentadienyl ( $\mathrm{Cp}$ ) ring protons shifted significantly downfield of about 3.5 and $0.8 \mathrm{ppm}$, respectively. The protons of the moiety derived from 1 were comparatively less affected (Figures S3 and S7). The protons near the newly formed carbamate bond shifted slightly (0.05-1 ppm) upfield. Interestingly, a slight doubling of peaks of the substituted $\mathrm{Cp}$ ring was observed in both ${ }^{1} \mathrm{H}$ - and ${ }^{13} \mathrm{C}-\mathrm{NMR}$ spectra in $\mathrm{CDCl}_{3}$ (Figures S3, S8 and S9). Similar effects have been reported for ferrocenyl amides of 1-aminoferrocene-1'-carboxylic acid by Heinze and coworkers ${ }^{20}$ and were attributed to a hydrogen-bonded dimer formed in non-coordinating solvents. Indeed, in $d_{8}-\mathrm{THF}$, the ${ }^{1} \mathrm{H}$ NMR spectrum of 2 still displayed the double signal (Figure S4), but its ${ }^{13} \mathrm{C}-\mathrm{NMR}$ showed only single peaks for the substituted Cp moiety (Figure S9).

Likewise, $\mathbf{F c}-\mathrm{NH}_{2}$ was caged with an o-nitrobiphenyl based photo-linker 3 which was previously developed by Goeldner and coworkers (Scheme $2 \mathrm{~B}$ ). ${ }^{21}$ We recently reported a 
derivative of this cage to which a targeting peptide can be attached via click chemistry. ${ }^{22}$ Here, we introduced a maleimide function to allow for coupling of thiol-containing biomolecules. Activation with disuccinimdyl carbonate and subsequent coupling to $\mathbf{F c}-\mathbf{N H}_{\mathbf{2}}$ gave the second caged derivative 4 . The product was fully characterized by ${ }^{1} \mathrm{H}$ and ${ }^{13} \mathrm{C} N M R$ (Figures S21 and S22), IR spectroscopy, and high resolution mass spectrometry. In the ${ }^{1} \mathrm{H}$ NMR spectrum, possible shifts of the proton signals belonging to the substituted $\mathrm{Cp}$ ring are not traceable since the protons of the tetraethylene glycol linker are detected in the same region. However, in analogy with 2 (Figure S3) and in contrast to 3 (Figure S19), the multiplet in that region expands down to $4.7 \mathrm{ppm}$. This indicates that attachment of $\mathbf{F c}-\mathbf{N H}_{\mathbf{2}}$ to 3 resulted in the same electronic changes due to the carbamate bond formation.

The photo-caged aminoferrocenes $\mathbf{2}$ and $\mathbf{4}$ were then conjugated to a mitochondria localization signal peptide (MLS) via Michael addition of the cysteine thiol of the peptide to the maleimides of the PLPGs (Scheme 2). After preparative HPLC purification and lyophilisation, 5 and $\mathbf{6}$ were obtained as light-yellow solids. For $\mathbf{5}$, the presence of the desired product was confirmed by ESI-MS where peaks at $m / z=352[\mathrm{M}+3 \mathrm{H}]^{3+}, 528.1$ $[\mathrm{M}+2 \mathrm{H}]^{2+}$ and $1055.4[\mathrm{M}+\mathrm{H}]^{+}$(Figure S13) were observed. As for the photo-caged rhenium (I) bioconjugate, ${ }^{15}$ small $\mathrm{m} / \mathrm{z}$ peaks corresponding to products of photo-uncaging (onitrobiphenyl cage with MLS peptide, and Fc-NH-COOH) were observed in the LC-MS spectra. This uncaging process happened due to the harsh ionization conditions used for LC-MS as uncaged complex and byproducts eluted at different times (Figures S14 and 36). Successful synthesis of 6 was confirmed by ESI-MS where $m / z=436[\mathrm{M}+3 \mathrm{H}]^{3+}, 654$ $[\mathrm{M}+2 \mathrm{H}]^{2+}$ and $1307[\mathrm{M}+\mathrm{H}]^{+}$(Figure S24) were detected. The purities were checked by analytical HPLC (Figure S23). 


\section{X-Ray Crystallography}

Single crystals of $\mathbf{2}$ suitable for $\mathrm{X}$-ray analysis were obtained by vapor diffusion recrystallization (see X-ray crystallographic part in the experimental section). The structure was solved with direct methods using SIR9733 and was refined by full-matrix least-squares methods on F2 with SHELXL-97 (see Table S1 in the Supporting Information). Only a few Xray structures of compounds consisting of 1-(2'-nitrophenyl)ethyl ester unit are known, ${ }^{23,24,25}$ but only two of them were actually synthesized as precursors for photolabile substances. ${ }^{23,24}$ 2 crystallized in the centrosymmetric triclinic space group $P-1$ and is in an overall bent conformation, essentially like a horseshoe, where the two ends, ferrocene and maleimide, almost touch each other (Figure 1). Additionally, 2 forms in the solid state a dimer via two hydrogen bridges: The amide nitrogen $\mathrm{N} 1$ is in close contact with one of the maleimide oxygen atoms 06_\$1 (-x+2, -y+2, -z) at a distance of 2.9003(15) $\AA$ and the amide of that molecule back binds to the original molecule to build the cyclic dimer (Figure S11).

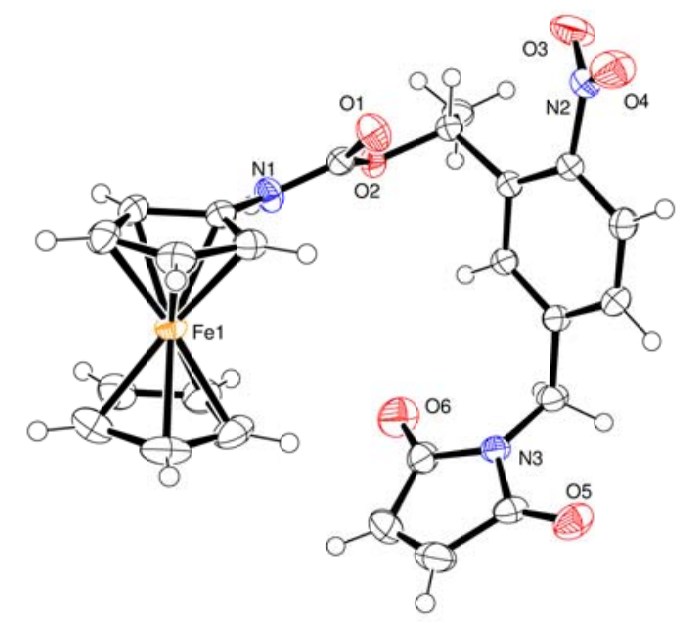

Figure 1. ORTEP representation of the crystal structure of 2. Ellipsoids were drawn at $50 \%$ probability.

\section{Photolysis Quantum Yields}

With the bioconjugates in hand, the next step in this study was to evaluate the photouncaging of 5 and 6 by measuring their laser photolysis quantum yield in PBS $(\mathrm{pH}=7.4)$ at $355 \mathrm{~nm}$. The decomposition of 5 and $\mathbf{6}$ was monitored by LC-MS until 20\% of the initial compound was photolysed (Figures S32-34). Calculated relative to the trans-to-cis photoisomerization quantum yield of azobenzene at this wavelength (15\%), ${ }^{26-28}$ a yield of $0.07 \pm 0.02 \%$ for $\mathbf{5}$ indicates a rather inefficient photo-release process, that runs much slower than the photolysis of the similar $\operatorname{Re}(\mathrm{I})$ bioconjugate. ${ }^{15}$ The carbamate-based photocages for amines first release the amine as a carbamate salt, which then in turn 
decarboxylates. ${ }^{11}$ The rate of decarboxylation depends on the $\mathrm{p} K_{\mathrm{a}}$ of the amine group and a more acidic aromatic amine of $\mathbf{F c}-\mathbf{N H}_{2}$ is expected to decarboxylate slower than an aliphatic amine of the reported $\operatorname{Re}(\mathrm{I})$ complex. However, we monitored the disappearance of $\mathbf{5}$ rather than the appearance of the released $\mathbf{F} \mathbf{c}-\mathbf{N H}_{\mathbf{2}}$. Hence, the observed slower decomposition cannot be ascribed to the decarboxylation step. Rapid photo-uncaging of the Re analogue could be ascribed to the high absorptivity of the $\operatorname{Re}(\mathrm{I})$ chromophore at the irradiation wavelength, which could enable it to act as an "light-antenna". Nevertheless, the photolysis quantum yield of 5 at $355 \mathrm{~nm}$ is also considerably lower than that of phosphate photo-caged with o-nitrophenyl group. ${ }^{26,28}$ An interference of the proximal ferrocene unit with the photochemistry cannot be excluded. The exact reasons, however, behind the particularly inefficient photo-release of $\mathbf{F c}-\mathbf{N H}_{2}$ from $\mathbf{5}$ are still speculative. The uncaging quantum yield of 6 was determined in a similar fashion. The quantum yield is with $1.8 \pm 0.48 \%$ higher than for $\mathbf{5}$, and is accompanied by a seven-fold higher absorptivity at $355 \mathrm{~nm}$ compared to $\mathbf{5}$ (see Figure 2). The propyl-o-nitrobiphenyl cage core has previously, to the best of our knowledge, not been used to cage amines via carbamates. A direct comparison regarding the uncaging quantum yield cannot therefore be made in this case.

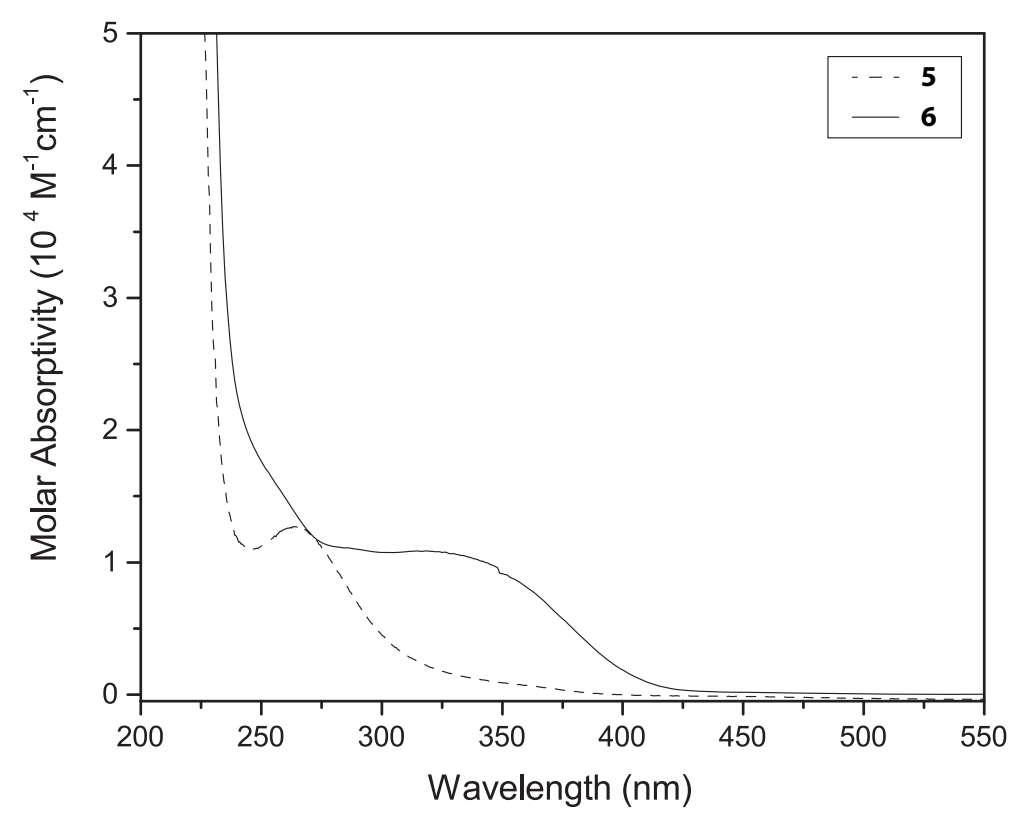

Figure 2. UV/Vis spectra of 5 and $\mathbf{6}$ in PBS buffer $(\mathrm{pH}=7.4)$.

\section{UV-A Irradiation and Iron Release}

Although a monochromatic laser setup allows for accurate determination of uncaging quantum yields, it is impractical for cell culture irradiation experiments. To this end, a UV-A reactor (Rayonet) equipped with lamps emitting in the 300-400 $\mathrm{nm}$ range (emission centered at $350 \mathrm{~nm}$ ) was used. To find a suitable UV-A light dose for the cell irradiation experiments, 
the more slowly uncaging $\mathbf{5}$ was photolysed under the same experimental setup as for cytotoxicity assays $(100 \mu \mathrm{M}$ in PBS buffer solution $(\mathrm{pH}=7.4)$ in a covered 96-well plate, $30^{\circ} \mathrm{C}$ ). As expected from the quantum yield measurements, the photolysis of 5 proceeded very slowly and required a relatively high light dose to complete $\left(18 \mathrm{~J} / \mathrm{cm}^{2}\right.$; Figure S31). Such elevated dose of UV-A light would on its own affect cell proliferation, so a maximal UV-A light dose safe for cells $\left(3.3 \mathrm{~J} / \mathrm{cm}^{2}\right)$ was used in cytotoxicity experiments. ${ }^{15}$ Using this light dose, neither the light irradiation nor secondary effects, e.g. temperature changes, affected the cells significantly. During irradiation experiments, the formation of $\mathbf{F c}-\mathbf{N H}_{2}$ and photo-cage byproducts was detected by LC-MS for $\mathbf{5}$ only (Figure S36). This is due to the fact that the sample solutions were adjusted to have the same absorbance at the irradiation wavelength. However, 5 has a significantly lower molar absorptivity at $355 \mathrm{~nm}$ compared to 6 (Figure 2). As a result, 5 was used in a considerably higher concentration and the products of its photolysis were easier to detect. The observation of products corresponding to the typical uncaging reaction are indicative of $\mathbf{F c}-\mathbf{N H}_{2}$ being released via the normal uncaging mechanism, as opposed to direct degradation of $\mathbf{F c}-\mathbf{N H}_{2}$. Of note, to observe the appearance of $\mathbf{F c}-\mathbf{N H}_{2}$, the samples had to be analyzed immediately after irradiation or kept frozen in liquid nitrogen prior to analysis due to the instability of $\mathbf{F c}-\mathbf{N H}_{\mathbf{2}}$. The $\mathbf{F c}-\mathbf{N H}_{2}$ peak initially increased with the light dose, but was not observed at higher doses (Figure S32). The irradiation of $\mathbf{F c}-\mathrm{NH}_{2}$ alone demonstrated that the compound decomposed faster than the caged $\mathbf{5}$ released it (Figure S35). The photo-decomposition of $\mathbf{F c}-\mathbf{N H}_{2}$ was also followed by UV/Vis spectroscopy (Figure S39). At a lower irradiation dose, the UV absorbance of the sample actually increases in the $250-350 \mathrm{~nm}$ range indicating formation of $\mathrm{Fc}^{+}$, which absorbs stronger than ferrocene in this range. ${ }^{29}$ Yet, at higher light doses, the characteristic Fc transitions in the $275-500 \mathrm{~nm}$ range decrease and then disappear completely.

Studies on aminoferrocene-based prodrug candidates' decomposition have shown that such molecules could decay into iron ions and cyclopentadienyl ligands. ${ }^{1,2}$ The release of iron ions played in fact an important role in the cytotoxicity mechanism of Mokhir's complexes as catalysts for ROS generation. ${ }^{1,2}$ To verify if the photo-decomposition of $\mathbf{5}, \mathbf{6}$ and $\mathbf{F} \mathbf{c}-\mathbf{N H}_{\mathbf{2}}$ resulted in the same products, the iron release upon light irradiation was monitored in PBS buffer $(\mathrm{pH}=7.4)$. More specifically, the compounds were irradiated by UV-A (as described above for UV-A dose determination) and the amount of free iron ions was quantified by formation of iron(II) tris(2,2'-bipyridine) complex and monitoring its strong absorption at $519 \mathrm{~nm} .{ }^{1}$ The assay showed that both $\mathbf{5}$ and $\mathbf{6}$ generated iron ions upon light irradiation, but long irradiation times were required to free up all iron (Figures S41-43). The iron release in the dark was also followed for $4 \mathrm{~h}$, but no significant increase in iron ions was detected (Figures S45 and 46). $\mathbf{F c}-\mathbf{N H}_{2}$, on the other hand, decomposed rapidly into iron ions even in 
the dark. Light irradiation only slightly increased the rate of iron release (Figure S43). These results demonstrate that the photo-caging of $\mathbf{F c}-\mathbf{N H}_{2}$ succeeds in enhancing its stability in aqueous media at physiological $\mathrm{pH}$. This effect is most likely due to decreased electron donation from the primary amino group, which is converted to a carbamate in $\mathbf{5}$ and $\mathbf{6}$. The decay into iron ions is clearly a complex multi-step process and the observed rate of $\mathbf{5}, \mathbf{6}$ and $\mathbf{F c}-\mathrm{NH}_{2}$ photolysis is consequently not always proportional to the appearance of iron ions. Indeed, although 5 decomposes considerably slower than 6 (see the quantum yields and absorptivities above), its iron release rate is only about 2-fold slower.

To verify that the iron ions are released as a consequence of the expected photo-induced nitrobenzene-uncaging reaction, 7 , which lacks the nitro group necessary for uncaging, was synthesized (see Figure 3 for the structure of the compound and the Supporting Information for experimental details). As a first control, we checked the stability of 7 in $d_{6}-D M S O: D_{2} O$ 3.5:1 (v:v) by $1 \mathrm{H}$ NMR spectrometry over $24 \mathrm{~h}$. As can be seen in Figure S27, no sign of decomposition was observed. The iron release of 7 relative to UV irradiation was then monitored like for the properly caged derivatives $\mathbf{5}$ and $\mathbf{6}$. As expected, no release of iron could be observed upon light irradiation (see Figure S44). Thus, the presence of the nitro group in $\mathbf{5}$ and $\mathbf{6}$ is necessary for the iron release. This observation supports the photouncaging mechanism. As a very important note of caution, we would like to highlight that a few iron detection assays have been recently put into question by Burdette for failing to consider the stability of $\mathrm{Fe}(\mathrm{II})$ and $\mathrm{Fe}$ (III) ions in water and the effect of other chemicals used in the assay. ${ }^{30}$ In particular, the use of phosphate buffer is questionable as the solubility of iron phosphate salts in water is extremely low. Our control experiments, however, demonstrate that iron 2,2'-bipyridine complex absorbance (quantified in iron detection) is equivalent in PBS $(\mathrm{pH}=7.4)$ and MOPS $(\mathrm{pH}=7.5)$ buffers at relevant concentrations (Figure S40). While our iron release results are plausible and fit with those of Mokhir et al., ${ }^{1}$ they should rather be interpreted qualitatively than quantitatively until the accuracy and precision of iron assays are fully validated. 
<smiles>CC(OC(=O)Nc1ccccc1Oc1ccccc1)c1ccccc1</smiles>

7<smiles>COc1ccc(-c2ccc([N+](=O)[O-])c(C(C)COC(=O)Nc3ccccc3)c2)cc1</smiles>

8

Figure 3. Structure of compounds $\mathbf{7}$ and $\mathbf{8}$ prepared for control experiment regarding the uncaging mechanism and the cytotoxicity mechanism, respectively (see Supporting Information for experimental details).

\section{Cytotoxicity}

The light-dependent anti-proliferative effect of 5, $\mathbf{6}$ and $\mathbf{F c}-\mathbf{N H}_{\mathbf{2}}$ was investigated on human promyelocytic leukemia (HL-60) and non-cancerous hTERT-immortalized retinal pigment epithelial (hTERT RPE-1) cell lines. To assess the light cytotoxicity, cells were incubated with the compounds for $4 \mathrm{~h}$ prior to irradiation. Afterwards, the cells were left to recover in the presence of the compounds for $46 \mathrm{~h}$. Dark toxicity was determined after $50 \mathrm{~h}$ incubation time in the dark. Cell viability was quantified using the resazurin assay ( $6 \mathrm{~h}$ incubation). As shown in Table 1, the dark cytotoxicity of $\mathbf{F c}-\mathbf{N H}_{2}$ towards $\mathrm{HL}-60$ was significantly decreased by derivatization with photo-protecting groups and peptide conjugation. Only a slight increase in cytotoxicity (1.3-1.5 fold) was observed for $\mathbf{F c}-\mathbf{N H}_{\mathbf{2}}$ and $\mathbf{5}$ upon light irradiation on $\mathrm{HL}-60$ cells. In the case of $\mathbf{F c}-\mathbf{N H}_{2}$, these results can be rationalized in terms of its instability. In fact, most of Fc- $\mathbf{N H}_{2}$ decomposed before the cells were irradiated (see Figure S43). The low cytotoxic impact of $\mathbf{5}$ can be explained by an extremely low uncaging efficiency of this compound. $\mathbf{6}$ is not as benign in the dark as $\mathbf{5}$, but possess an improved phototoxic index of about 2.5. Upon light irradiation, the $\mathrm{IC}_{50}$ value of $\mathbf{6}$ reaches the level of $\mathbf{F} \mathbf{c}-\mathbf{N H}_{\mathbf{2}}$. 
Table 1. Cytotoxicity $\left(\mathrm{IC}_{50}\right)$ of $\mathbf{5 , 6 , 8}$ and $\mathbf{F c}-\mathrm{NH}_{2}$ towards human cell lines.

\begin{tabular}{c|ccc|ccc}
\hline & \multicolumn{3}{|c|}{ HL-60 } & \multicolumn{3}{c}{ hTERT RPE-1 } \\
& $\begin{array}{c}\text { dark }^{a} \\
{[\mu \mathrm{M}]}\end{array}$ & $\begin{array}{c}\text { UV-A } \\
{[\mu \mathrm{M}]}\end{array}$ & $\begin{array}{c}\text { Phototoxic } \\
\text { Index }\end{array}$ & $\begin{array}{c}\text { dark }^{a} \\
{[\mu \mathrm{M}]}\end{array}$ & $\begin{array}{c}\text { UV-A }^{b} \\
{[\mu \mathrm{M}]}\end{array}$ & \begin{tabular}{c} 
Phototoxic $^{\text {Index }}$ \\
\hline Fc-NH
\end{tabular} \\
\hline $\mathbf{5}$ & $18.4 \pm 0.1$ & $12.1 \pm 0.7$ & $1.5 \pm 0.1$ & $42.4 \pm 9.2$ & $38.2 \pm 3.1$ & $1.1 \pm 0.3$ \\
$\mathbf{6}$ & $72.6 \pm 0.8$ & $55.4 \pm 3.9$ & $1.3 \pm 0.1$ & $>100$ & $>100$ & - \\
$\mathbf{8}^{c}$ & $70.0 \pm 0.6$ & $15.7 \pm 2.8$ & $2.5 \pm 0.4$ & $39.0 \pm 1.1$ & $37.1 \pm 2.9$ & $1.1 \pm 0.1$ \\
\hline
\end{tabular}

${ }^{a}$ incubated with the compounds for $56 \mathrm{~h}$ (including $6 \mathrm{~h}$ resazurin assay); ${ }^{b}$ incubated with the compounds for $4 \mathrm{~h}$ prior to irradiation (10 $\mathrm{min}, 3.3 \mathrm{~J} \cdot \mathrm{cm}^{-2}$, UV-A reactor at $350 \mathrm{~nm}$ ), then incubated for another $52 \mathrm{~h}$ (including $6 \mathrm{~h}$ resazurin assay); ${ }^{c} 24 \mathrm{~h}$ resazurin assay; n.d.: not determined.

Except for $\mathbf{6}$ in the dark, all tested iron containing compounds are less toxic towards noncancerous hTERT RPE-1 cells and show no effect of light-irradiation on this cell line. The difference is likely due to the elevated levels of ROS characteristic for tumors. This enhanced ROS generation pushes the ROS scavenging system of cancer cells to the limit and a further increase in ROS can tip the scale towards cellular death. The similar toxicity of 6 in the dark in HL-60 and hTERT RPE-1 cells could be explained by a ROS independent toxicity mechanism in this case. In order to test the hypothesis of the iron mediated redox mechanism, the cytotoxicity of the caged aniline derivative 8 was determined (see Figure 3 for the structure of $\mathbf{8}$ and the Supporting Information for experimental details). The uncaging quantum yield of 8 is with $2.9 \pm 0.22 \%$ slightly higher than the one of 6 . Nevertheless, the toxicity of $\mathbf{8}$ was found to be independent from light irradiation. Furthermore, no increased toxicity towards the cancer cell line HL-60 was found, compared to the hTERT RPE-1 cell line. Thus, the data indicate that the cytotoxicity mechanism of $\mathbf{5}, \mathbf{6}$ and $\mathbf{F c}-\mathbf{N H}_{\mathbf{2}}$ is likely to involve catalytic ROS generation by the liberated iron ions, as suggested by the Mokhir group for their aminoferrocene-based prodrug candidates. ${ }^{1,2}$ Indeed, the $\mathrm{IC}_{50}$ values of $\mathbf{5}, \mathbf{6}$ and $\mathbf{F c}-\mathrm{NH}_{2}$ on HL-60 cells are in the same range as those reported by the Mokhir group on the same cell line. 6 has in fact the $I_{50}$ value very close to that of the most toxic compound tested on HL-60 by Mokhir's group (15.7 \pm 2.8 vs $9 \pm 2) .{ }^{1}$ All in all, the data demonstrate that the activity of cytotoxic aminoferrocene compounds can be efficiently controlled by a photocaging strategy.

The direct quantification of the cellular uptake of our compounds remains challenging as it cannot be monitored by conventional methods such as fluorescence microscopy, atomic absorption spectrometry or inductively coupled plasma-mass spectrometry. However, additional indirect information could be obtained by evaluating, for example, the cellular ROS production, the change in the mitochondrial membrane potential or in cellular respiration. 
Further studies are therefore required to elucidate the efficiency of targeting vectors and the anti-proliferative effect of $\mathbf{5}$ and $\mathbf{6}$ in more detail.

\section{Conclusion}

In this work, we have successfully prepared and characterized two light-activatable aminoferrocene-based prodrug candidates (5 and $\mathbf{6})$ using two different photo-cages. Upon UV-A light irradiation, both bioconjugates released aminoferrocene, which rapidly decayed into iron ions under physiological conditions. Despite this decomposition - or most likely due to it - aminoferrocene considerably reduced the proliferation of cancer cells (HL-60) both in dark and upon light irradiation. While both cages improved the stability of aminoferrocene and therefore attenuated its dark cytotoxicity, 6 displayed a higher uncaging efficiency, higher phototoxic index and lower light $\mathrm{IC}_{50}$ value compared to $\mathbf{5}$. Importantly, the absence of cytotoxicity upon light irradiation of $\mathbf{5}$ and $\mathbf{6}$ on non-cancerous cells contrary to cancer cells suggests that these compounds exploit the elevated ROS levels typical of cancer cells. Their mode of action is then likely based on the catalysis of ROS generation by released iron ions. In addition to the selectivity derived from this inherent property of the tumors, our photocaged aminoferrocene prodrug candidates also offer spatial and temporal control of their activity via light irradiation. Besides, PLPGs offer a possibility of derivatization with a targeting vector. We believe that this concept holds great potential, especially when considering the severe side-effects frequently encountered by patients undergoing chemotherapy. Importantly, the currently greatest shortcoming of the system, the need for irradiation with potentially harmful and relatively lowly tissue penetrating UV light could in future studies be avoided by the use of two-photon uncaging with light in the near-IR range. ${ }^{22,31}$

\section{Experimental Section}

\section{Materials and Instruments}

Chemicals and solvents were purchased reagent grade or better from commercial suppliers and used without further purification unless otherwise specified. Reactions with potentially photo-labile components were carried out under exclusion of light. ${ }^{1} \mathrm{H}$ and ${ }^{13} \mathrm{C}$ NMR spectra were recorded with Bruker 400 and 500 spectrometers. The chemical shifts were referenced relative to the solvent signals. UV/Vis spectra were recorded on Varian Cary 50 Scan and Cary 100 spectrophotometers. ESI-MS and LC-MS were obtained with a Bruker Daltonics 
HCT 6000 mass spectrometer. LC-MS spectra were measured on an Acquity ${ }^{\mathrm{TM}}$ from Waters system equipped with a PDA detector and an auto sampler using an Agilent Zorbax $300 \mathrm{SB}-$ C18 analytical column ( $3.5 \mu \mathrm{m}$ particle size, $300 \AA$ pore size, $150 \times 4.6 \mathrm{~mm})$. The LC run (flow rate: $0.3 \mathrm{~mL} \mathrm{~min}^{-1}$ ) was performed with a linear gradient of $A$ (distilled water containing $0.1 \% \mathrm{v} / \mathrm{v}$ formic acid) and $\mathrm{B}$ (acetonitrile, containing $0.1 \% \mathrm{v} / \mathrm{v}$ formic acid); $\mathrm{t}=0 \mathrm{~min}, 5 \% \mathrm{~B}$; $\mathrm{t}=3 \mathrm{~min}, 5 \% \mathrm{~B} ; \mathrm{t}=17 \mathrm{~min}, 100 \% \mathrm{~B} ; \mathrm{t}=20 \mathrm{~min}, 100 \% \mathrm{~B} ; \mathrm{t}=25 \mathrm{~min}, 5 \% \mathrm{~B}$. Analytical HPLC was carried out using a Macherey-Nagel EC 250/3 NUCLEOSIL 100-5 C18 column on a VWR Chromaster system with 5110 pump, 5210 autosampler, 5310 column oven and 5430 diode array detector. Analytical HPLC run (flow rate $1 \mathrm{~mL} / \mathrm{min}$ ) were performed with a linear gradient of $A$ (distilled water containing $0.1 \% \mathrm{v} / \mathrm{v}$ TFA) and $B$ (acetonitrile): $\mathrm{t}=0 \mathrm{~min}, \mathrm{~B}=5 \%$; $t=18 \min , B=39 \% ; t=27 \min , B=100 \% ; t=31 \min , B=100 \% ; t=36 \min , B=1 \% ; t=$ $38 \mathrm{~min}, \mathrm{~B}=1 \%, \mathrm{t}=40 \mathrm{~min}, \mathrm{~B}=5 \% ; \mathrm{t}=41 \mathrm{~min}, \mathrm{~B}=5$ ), unless noted otherwise. HPLC purification was performed on a Varian ProStar system using an Agilent PrepHT 300SB-C18 preparative column $(5 \mu \mathrm{m}$ particle size, $300 \AA$ pore size, $150 \times 21.1 \mathrm{~mm}$. Flow rate: $20 \mathrm{~mL} \mathrm{~min}{ }^{-1}$ ). The runs were performed with a linear gradient of $A$ (distilled water containing $0.1 \% \mathrm{v} / \mathrm{v}$ TFA) and B (acetonitrile (Sigma-Aldrich HPLC-grade), containing $0.1 \% \mathrm{v} / \mathrm{v}$ TFA), unless noted otherwise. Photolysis quantum yields were measured using an Edinburgh LP920 setup equipped with a Continuum Surelite laser $(355 \mathrm{~nm})$. Cell culture photo-irradiation and iron release assays were conducted using a Rayonet RPR-200 photochemical reactor using 6 bulbs ( $14 \mathrm{~W}$ each) emitting in $300-400 \mathrm{~nm}$ range with maximum intensity output at $350 \mathrm{~nm}$. The temperature inside the reactor was $30^{\circ} \mathrm{C}$. The light intensity was $55 \mathrm{~W} / \mathrm{m}^{2}$, as determined with a X $1{ }_{1}$ optometer (Gigahertz-Optik).

\section{Synthesis and Characterization}

\section{Fc- $\mathrm{NH}_{2}$}

Aminoferrocene was prepared using a procedure previously published. ${ }^{32}$ The analytical data matched what that previously reported. ${ }^{32}$

\section{Compound 1}

The photolinker was synthesized following a procedure previously published. ${ }^{17}$ The analytical data matched what that previously reported. ${ }^{17}$ 


\section{Compound 2}

1 (30 mg, $0.072 \mathrm{mmol}$ ) and aminoferrocene (15 $\mathrm{mg}, 0.072 \mathrm{mmol}$ ) were dissolved in dry chloroform (1 mL). Diisopropylethylamine $(24 \mathrm{mg}, 31 \mu \mathrm{L}, 0.18 \mathrm{mmol})$ was then added to the mixture, which was stirred for $4 \mathrm{~h}$ at $35^{\circ} \mathrm{C}$. The solvent was then removed under vacuum to give a sticky brown solid, which was purified by column chromatography (silica gel, $\mathrm{CH}_{2} \mathrm{Cl}_{2} /$ EtOAc 9:1) to afford 2 as an orange-red solid (22 $\mathrm{mg}, 62 \%$ ).

$R_{\mathrm{f}}=0.86\left(\mathrm{CH}_{2} \mathrm{Cl}_{2} / \mathrm{EtOAc} 9: 1\right) .{ }^{1} \mathrm{H}$ NMR $\left(500 \mathrm{MHz}, \mathrm{CDCl}_{3}\right) \delta 7.92\left(\mathrm{~d},{ }^{3} \mathrm{~J}=8.5 \mathrm{~Hz}, 1 \mathrm{H}\right), 7.64$ (s, 1H), $7.39\left(\mathrm{~d},{ }^{3} \mathrm{~J}=8.5 \mathrm{~Hz}, 1 \mathrm{H}\right), 6.67(\mathrm{~s}, 2 \mathrm{H}), 6.29\left(\mathrm{q},{ }^{3} \mathrm{~J}=6.5 \mathrm{~Hz}, 1 \mathrm{H}\right), 6.02(\mathrm{~s}, 1 \mathrm{H}), 4.71(\mathrm{~s}$, $2 \mathrm{H}), 4.49(\mathrm{~m}, 1 \mathrm{H}), 4.46(\mathrm{~m}, 1 \mathrm{H}), 4.15(\mathrm{~s}, 5 \mathrm{H}), 3.98(\mathrm{~m}, 1 \mathrm{H}), 1.63\left(\mathrm{~d},{ }^{3} \mathrm{~J}=6.5,3 \mathrm{H}\right) .{ }^{13} \mathrm{C}$ NMR $\left(125 \mathrm{MHz}, \mathrm{CDCl}_{3}\right) \delta 170.2,152.6,147.0,142.1,139.4,134.5,128.6,127.5,125.5,69.5$, $69.0,64.7,64.6,60.9,60.8,40.9,22.3$, one signal coincidental or not observed. ESI-MS calcd. for $\mathrm{C}_{24} \mathrm{H}_{21} \mathrm{FeN}_{3} \mathrm{O}_{6}[\mathrm{M}]^{+}$503.3, found 503.1. ESI-HRMS m/z calcd. for $\mathrm{C}_{24} \mathrm{H}_{21} \mathrm{FeN}_{3} \mathrm{O}_{6}$ $\left([\mathrm{M}]^{+}\right)$503.0780, found 503.0778; calcd. for $\mathrm{C}_{24} \mathrm{H}_{21} \mathrm{FeN}_{3} \mathrm{O}_{6} \mathrm{Na}\left([\mathrm{M}+\mathrm{Na}]^{+}\right)$526.0677, found 526.0673; calcd. for $\mathrm{C}_{24} \mathrm{H}_{21} \mathrm{FeN}_{3} \mathrm{O}_{6} \mathrm{~K}\left([\mathrm{M}+\mathrm{K}]^{+}\right)$542.0417, found 542.0411; calcd. for $\mathrm{C}_{19} \mathrm{H}_{16} \mathrm{FeN}_{3} \mathrm{O}_{6}\left([\mathrm{M}-\mathrm{Cp}]^{+}\right)$438.0389, found 438.0871; calcd. for $\mathrm{C}_{11} \mathrm{H}_{11} \mathrm{FeNO}_{2}\left([\mathrm{FcNHCOOH}]^{+}\right)$ 245.0139, found 245.0130 .

\section{MLS peptide}

The peptide was prepared following a previously published general peptide synthesis procedure. $^{33}$

ESI-MS m/z calcd. for $\mathrm{C}_{24} \mathrm{H}_{41} \mathrm{~N}_{9} \mathrm{O}_{4} \mathrm{~S}\left([\mathrm{M}+\mathrm{H}]^{+}\right)$552.3, found 552.3; calcd. for $\mathrm{C}_{24} \mathrm{H}_{42} \mathrm{~N}_{9} \mathrm{O}_{4} \mathrm{~S}$ $\left([\mathrm{M}+2 \mathrm{H}]^{2+}\right) 276.7$, found 276.6 .

\section{Compound 5}

$2(20 \mathrm{mg}, 40 \mu \mathrm{mol})$ and MLS peptide $(35 \mathrm{mg}, 40 \mu \mathrm{mol})$ were first pre-dissolved in DMSO $(30 \mu \mathrm{L})$ and then in acetonitrile/water mixture 1:1 $(1 \mathrm{~mL})$. The reaction mixture was stirred overnight at room temperature. The solvents were removed by lyophilization and the compound was purified by preparative HPLC to obtain it as a light-yellow solid. Preparative HPLC run: $\mathrm{t}=0 \mathrm{~min}, 5 \% \mathrm{~B} ; \mathrm{t}=25 \mathrm{~min}, 100 \% \mathrm{~B} ; \mathrm{t}=30 \mathrm{~min}, 100 \% \mathrm{~B} ; \mathrm{t}=32 \mathrm{~min}, 5 \% \mathrm{~B} ; \mathrm{t}_{\mathrm{R}}$ $=18.6 \mathrm{~min}$.

ESI-MS m/z calcd for $\mathrm{C}_{48} \mathrm{H}_{62} \mathrm{FeN}_{12} \mathrm{O}_{10} \mathrm{~S}\left([\mathrm{M}+\mathrm{H}]^{+}\right)$1055.4, found 1055.4; calcd for $\mathrm{C}_{48} \mathrm{H}_{63} \mathrm{FeN}_{12} \mathrm{O}_{10} \mathrm{~S}\left([\mathrm{M}+2 \mathrm{H}]^{2+}\right)$ 528.2, found 528.1; calcd for $\mathrm{C}_{48} \mathrm{H}_{64} \mathrm{FeN}_{12} \mathrm{O}_{10} \mathrm{~S}\left([\mathrm{M}+3 \mathrm{H}]^{3+}\right)$ 352.3, found 352.2. UV absorption (PBS buffer, $\mathrm{pH}=7.4): \varepsilon(\lambda=264 \mathrm{~nm})=13037 \mathrm{M}^{-1} \mathrm{~cm}^{-1}$; $\varepsilon(\lambda=355 \mathrm{~nm})=1235 \mathrm{M}^{-1} \mathrm{~cm}^{-1}$. 


\section{Compound 4}

Under an atmosphere of $\mathrm{N}_{2}, N, N^{\prime}$-disuccinimidyl carbonate $(70.3 \mathrm{mg}, 0.275 \mathrm{mmol})$ was added to a solution of 3 (see Supporting Information; $82.9 \mathrm{mg}, 0.157 \mathrm{mmol}$ ) in acetonitrile $(2 \mathrm{~mL})$. Triethylamine $(76.6 \mu \mathrm{L}, 55.6 \mathrm{mg}, 0.549 \mathrm{mmol})$ was added to the stirred suspension, and stirring was continued for $6.5 \mathrm{~h}$. All volatiles were removed on a rotary evaporator. The remaining residue was taken up in EtOAc and washed with $0.1 \mathrm{M} \mathrm{NaHCO}_{3}$. The layers were separated and the aqueous layer was twice extracted with EtOAc. The combined organic layers were washed with brine, dried $\left(\mathrm{Na}_{2} \mathrm{SO}_{4}\right)$, filtered and concentrated. Column chromatography (silica gel, $\mathrm{CH}_{2} \mathrm{Cl}_{2} / \mathrm{EtOAc}$ 8:2) yielded the intermediate active ester of $\mathbf{3}$ as a yellow oil (55 mg, would correspond to $52 \%$ ), which was directly used in the next reaction step.

The active ester of 3 (21 mg, would correspond to $31 \mu \mathrm{mol})$, aminoferrocene $(8.2 \mathrm{mg}$, $41 \mu \mathrm{mol})$ and diisopropylethylamine $(6.5 \mathrm{mg}, 8.5 \mu \mathrm{L}, 50 \mu \mathrm{mol})$ were dissolved in dry $\mathrm{CH}_{2} \mathrm{Cl}_{2}$ $(4 \mathrm{~mL})$ and stirred under exclusion of light for $15 \mathrm{~h}$ at rt. Saturated $\mathrm{NH}_{4} \mathrm{Cl}$ solution was added and the mixture extracted with $\mathrm{CH}_{2} \mathrm{Cl}_{2}(3 \mathrm{x})$. The combined organic layers were dried $\left(\mathrm{MgSO}_{4}\right)$, filtered and concentrated. Purification by column chromatography (silica gel, $\mathrm{CH}_{2} \mathrm{Cl}_{2} / \mathrm{MeOH} 200: 1 \rightarrow 98: 2$ ) gave pure 4 as brown viscous oil $\left(23 \mathrm{mg}, 96 \%\right.$ for $2^{\text {nd }}$ step, 50\% over both steps).

$R_{\mathrm{f}}=0.46\left(\mathrm{CH}_{2} \mathrm{Cl}_{2} / \mathrm{MeOH}\right.$ 95:5). IR (neat) 3095(w), $2874(\mathrm{w}), 1702(\mathrm{~s}), 1604(\mathrm{~m}), 1515$ (s), $1346(\mathrm{~m}), 1232(\mathrm{~m}), 1103(\mathrm{~m}), 1074(\mathrm{~m}), 932(\mathrm{w}), 824(\mathrm{~s}), 695(\mathrm{~m}) \mathrm{cm}^{-1} .{ }^{1} \mathrm{H}$ NMR $(500 \mathrm{MHz}$, $\left.\mathrm{CDCl}_{3}\right) \partial 7.85(\mathrm{~d}, J=7.9 \mathrm{~Hz}, 1 \mathrm{H}), 7.69-7.42(\mathrm{~m}, 4 \mathrm{H}), 7.02(\mathrm{~d}, J=7.9 \mathrm{~Hz}, 2 \mathrm{H}), 6.67(\mathrm{~s}, 2 \mathrm{H})$, $5.72(\mathrm{bs}, 1 \mathrm{H}), 4.73-3.30(\mathrm{~m}, 28 \mathrm{H}), 1.41(\mathrm{~d}, J=6.5 \mathrm{~Hz}, 3 \mathrm{H}) .{ }^{13} \mathrm{C} \mathrm{NMR}\left(125 \mathrm{MHz}, \mathrm{CDCl}_{3}\right): \partial$ $170.6,159.5,153.2,149.0,145.4,138.0,134.1,131.5,128.5,125.9,125.4,125.0,115.2$, $70.9,70.7,70.6,70.1,69.6,69.5,68.8,67.8,67.6,64.7,60.6,37.1,33.3,17.4$, one signal coincidental or not observed. ESI-MS m/z $778.2\left(100,[\mathrm{M}+\mathrm{Na}]^{+}\right), 755.2\left(49,[\mathrm{M}]^{+}\right), 389.1(88$, $\left.[\mathrm{M}+\mathrm{Na}]^{2+}\right)$. HRMS m/z calcd. for $\mathrm{C}_{38} \mathrm{H}_{41} \mathrm{~N}_{3} \mathrm{O}_{10}\left([\mathrm{M}]^{+}\right)$755.21358, found 755.20277.

\section{Compound 6}

$4(20 \mathrm{mg}, 26 \mu \mathrm{mol})$ and MLS peptide $(15 \mathrm{mg}, 26 \mu \mathrm{mol})$ were dissolved in a mixture of acetonitrile $(2 \mathrm{~mL})$ and PBS buffer $(1 \mathrm{~mL})$. The solution was stirred for $7 \mathrm{~h}$ at $\mathrm{rt}$. The solvents were removed by lyophilization. Purification by preparative HPLC $\left(20 \mathrm{~mL} / \mathrm{min}, \mathrm{H}_{2} \mathrm{O}+0.1 \%\right.$ TFA : acetonitrile = 0 min: 95:5, $27 \min :$ 35:65, $31 \min :$ 0:100, 33 min: 0:100, $36 \min :$ 95:5, 37 min: 95:5, $t_{R}=13 \mathrm{~min}$ ) gave pure 6 as a brown solid. 
ESI-MS m/z $654\left(100,[\mathrm{M}+2 \mathrm{H}]^{2+}\right), 436\left(40,[\mathrm{M}+3 \mathrm{H}]^{3+}\right), 1307\left(8,[\mathrm{M}+\mathrm{H}]^{+}\right) . t_{R}=22.6 \mathrm{~min}$ (HPLC analytical gradient). UV absorption (PBS buffer, $\mathrm{pH}=7.4): \varepsilon(\lambda=355 \mathrm{~nm})=$ $8732 \mathrm{M}^{-1} \mathrm{~cm}^{-1}$.

\section{X-Ray Crystallography}

Crystals were grown by vapour diffusion of cyclohexane into a solution of $\mathbf{2}$ in methylene chloride. ${ }^{34}$ Crystallographic data were collected at $183(2) \mathrm{K}$ with Mo $\mathrm{K}_{\alpha}$ radiation $(\lambda=$ $0.7107 \AA$ ) that was graphite-monochromated on an Oxford Diffraction CCD Xcalibur system with a Ruby detector. Suitable crystals were covered with oil (Infineum V8512, formerly known as Paratone $\mathrm{N}$ ), placed on a nylon loop that is mounted in a CrystalCap Magnetic ${ }^{\mathrm{TM}}$ (Hampton Research) and immediately transferred to the diffractometer. The program suite CrysAlis $^{\text {Pro }}$ was used for data collection, multi-scan absorption correction and data reduction. ${ }^{35}$ The structure was solved with direct methods using $S I R 97^{36}$ and was refined by full-matrix least-squares methods on $\mathrm{F}^{2}$ with SHELXL-97. ${ }^{37}$

\section{Photophysical Characterization}

\section{Photolysis quantum yield}

$20 \mathrm{mM}$ DMSO stock solutions of 5 and $\mathbf{6}$ were diluted in phosphate buffer $(\mathrm{pH}=7.4)$ to obtain optical density at $355 \mathrm{~nm}(\mathrm{OD}(\lambda=355 \mathrm{~nm}))$ of 0.2 . Fluorescence cuvette $(1 \mathrm{~cm} \times 0.2 \mathrm{~cm}$, Hellma 105.250-QS with $100 \mu \mathrm{L}$ of solution was irradiated at $355 \mathrm{~nm}$ using an Edinburgh LP920 laser flash photolysis setup equipped with a Continuum Surelite Nd:YAG laser, frequency tripled to generate light with a wavelength of $355 \mathrm{~nm}$. The laser beam was slightly misaligned to obtain a suitable irradiation power. A fresh aliquot of solution was used for each irradiation. After a certain number of laser shots the solutions were transferred to amber HPLC vials with a $200 \mu \mathrm{L}$ inlet. The vials were then kept frozen in liquid nitrogen and unfrozen 2 min prior to analysis by LC-MS due to the instability of released aminoferrocene. The peak corresponding to $\mathbf{5}$ or $\mathbf{6}$ was integrated and the percentage of remaining compound (calculated from the peak area) was plotted against the number of laser shots. The experiment was continued until the number of laser shots that decomposed $20 \%$ of 5 or 6 was reached. At less than $20 \%$ conversion, the photolysis curve could be fitted by a simple linear regression. The slope of the linear fit msample was then used to calculate the photolysis quantum yield by comparing it to the quantum yield of azobenzene photoisomerization. For that, trans-azobenzene was dissolved in methanol to obtain $\operatorname{OD}(\lambda=$ $355 \mathrm{~nm})=0.2$ and irradiated in the same conditions as $\mathbf{5}$ and $\mathbf{6}$. The conversion of 
azobenzene was monitored by following the UV/Vis absorbance at $355 \mathrm{~nm}$. The irradiation was continued until $20 \%$ of azobenzene had isomerized. The percentage of remaining amount of trans-azobenzene was then plotted versus the irradiation dose (measured in number of laser shots) and fitted by a linear curve as for $\mathbf{5}$ and $\mathbf{6}$ (see above). The slope of azobenzene curve $m_{\text {referemen }}$ was used to calculate the photolysis quantum yield of $\mathbf{5}$ or $\mathbf{6}$ $\left(\phi_{\text {sample }}\right)$ using the following equation:

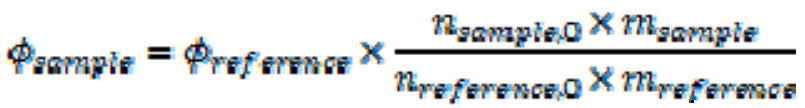

where $\phi_{\text {referemos }}$ is the quantum yield of azobenzene trans-cis isomerization at $355 \mathrm{~nm}$ $(15 \%)$, and $n_{0}$ are the amounts (in mol) of the respective compounds before irradiation. At least three independent sets of experiments were averaged to obtain the single-photon uncaging quantum yields.

\section{Photolysis in UV reactor}

To estimate the UV-A dose needed for $\mathbf{5}$ uncaging in cells, $20 \mathrm{mM}$ DMSO stock solution of it was diluted with PBS buffer $(\mathrm{pH}=7.4)$ to obtain a final concentration of $100 \mu \mathrm{M}$ (highest concentration used in cytotoxicity experiments). The solution was pipetted in $100 \mu \mathrm{L}$ portions on a 96-well plate (used for cytotoxicity experiments) and irradiated in the UV reactor with different light doses. The solution composition was analyzed by LC-MS immediately after irradiation. The relative concentration of the photolysed compound was calculated from the area of the corresponding LC-MS peak. Percentage of remaining compound vs. the irradiation dose could be fitted by a single exponential (first order kinetics law):

$C(x)=C_{0} \times e^{-k x}$

where $C_{0}$ is the initial concentration, $k$ is the rate constant and $x$ is the irradiation dose. The same procedure was applied for aminoferrocene to monitor its decomposition during UV-A irradiation.

\section{Iron release}

Release of iron ions from $\mathbf{F c}-\mathbf{N H}_{2}, \mathbf{5}, \mathbf{6}$ and $\mathbf{7}$ was monitored using a procedure adapted from Mokhir's work. ${ }^{1}$ More specifically, the compound of interest $(5 \mu \mathrm{L}, 4 \mathrm{mM}$ DMSO stock solution) was diluted in PBS $(\mathrm{pH}=7.4,175 \mu \mathrm{L})$. The concentration of iron ions was then 
detected by addition of $\mathrm{Na}_{2} \mathrm{~S}_{2} \mathrm{O}_{4}(10 \mu \mathrm{L}, 0.8 \mathrm{M}$ in water) and 2,2'-bipyridine (10 $\mu \mathrm{L}, 12 \mathrm{mM}$ in DMF:water 1:1), which forms iron(II) tris(2,2'-bipyridine) complex. The amount of formed complex was quantified by observing its strong absorbance at $509 \mathrm{~nm}$. The experiments were conducted in a 96-well plate using a Spectramax $\mathrm{M}^{\mathrm{e}}$ microplate reader (Molecular Devices).

\section{Cell Culture}

The human promyelocytic leukemia cells (HL-60) were cultured in RPMI (Gibco) supplemented with $20 \%$ heat inactivated fetal calf serum (Gibco), $100 \mathrm{U} / \mathrm{mL}$ penicillin, $100 \mu \mathrm{g} / \mathrm{mL}$ streptomycin at $37^{\circ} \mathrm{C}$ and $5 \% \mathrm{CO}_{2}$. The hTERT-immortalized retinal pigment epithelial cell line (hTERT RPE-1) was maintained in DMEM (Gibco) supplemented with 10\% FCS (Gibco), $100 \mathrm{U} / \mathrm{mL}$ penicillin, $100 \mu \mathrm{g} / \mathrm{mL}$ streptomycin at $37^{\circ} \mathrm{C}$ and $5 \% \mathrm{CO}_{2}$.

\section{Photo-toxicity studies}

Photo-toxicity studies were performed on two different cell lines, namely HL-60 and hTERT RPE-1, by a fluorometric cell viability assay using resazurin (Promocell $\mathrm{GmbH}$ ). Briefly, one day before treatment, cells were plated in triplicates in 96-well plates at a density of $4 \times 10^{3}$ cells/well in $100 \mu \mathrm{L}$. Cells were then treated with increasing concentrations of the complexes for $50 \mathrm{~h}$. For light toxicity measurements, the cells were irradiated $4 \mathrm{~h}$ after beginning of the treatment for $10 \mathrm{~min}$ at $350 \mathrm{~nm}\left(3.3 \mathrm{~J} / \mathrm{cm}^{2}\right)$ and then placed back in the incubator in the dark for the remaining $44 \mathrm{~h}$. The cell medium was not replaced. After treatment, resazurin $(0.2 \mathrm{mg} / \mathrm{mL}$ final concentration) was added to the $200 \mu \mathrm{L}$. After $6 \mathrm{~h}$ of incubation at $37^{\circ} \mathrm{C}(24 \mathrm{~h}$ for 8), the fluorescence of the highly red fluorescent resorufin product was quantified at $590 \mathrm{~nm}$ emission with $540 \mathrm{~nm}$ excitation wavelength in a SpectraMax M5 microplate reader.

\section{Associated Content}

The Supporting Information is available free of charge on the ACS Publication website at DOI: 10.1021/acs.inorg-chem.XXXXXX.

Synthetic procedures for precursors and control compounds; NMR spectra; mass spectra; UV/Vis spectra; photolysis plots; iron release plots; crystallographic table. 


\section{Acknowledgments}

This work was supported by the Swiss National Science Foundation (Professorships $\mathrm{N}^{\circ}$ PP00P2_133568 and PP00P2_157545, and Research Grants N²00021_129910 and N 200020_146776 to G.G.), the University of Zurich (G.G. and S.F.), the Stiftung für Wissenschaftliche Forschung of the University of Zurich (G.G. and S.F.), the Stiftung zur Krebsbekämpfung (S.F.), the Huggenberger-Bischoff Stiftung (S.F.), the COST Action CM1105 (G.G.) and the University of Zurich Priority Program (S.F.). The authors would also like to thank Yanjun Lan for her help with the scaled-up synthesis of 1 and Elisa Fusini for her help for the NMR studies of the stability of 7 . 


\section{References}

(1) Hagen, H.; Marzenell, P.; Jentzsch, E.; Wenz, F.; Veldwijk, M. R.; Mokhir, A. J. Med. Chem. 2012, 55, 924-934.

(2) Marzenell, P.; Hagen, H.; Sellner, L.; Zenz, T.; Grinyte, R.; Pavlov, V.; Daum, S.; Mokhir, A. J. Med. Chem. 2013, 56, 6935-6944.

(3) a) Kashfi, K.; Rigas, B. Biochem. Biophys. Res. Commun. 2007, 358, 1096-1101; b) Hulsman, N.; Medema, J. P.; Bos, C.; Jongejan, A.; Leurs, R.; Smit, M. J.; de Esch, Iwan J. P.; Richel, D.; Wijtmans, M. J. Med. Chem. 2007, 50, 2424-2431.

(4) a) Hamels, D.; Dansette, P. M.; Hillard, E. A.; Top, S.; Vessières, A.; Herson, P.; Jaouen, G.; Mansuy, D. Angew. Chem. Int. Ed. 2009, 48, 9124-9126; b) Hillard, E.; Vessières, A.; Thouin, L.; Jaouen, G.; Amatore, C. Angew. Chem. Int. Ed. 2006, 45, 285290.

(5) a) Knox, G. R.; Pauson, P. L. J. Chem. Soc. 1961, 4615-4618; b) Britton, W. E.; Kashyap, R.; El-Hashash, M.; El-Kady, M.; Herberhold, M. Organometallics. 1986, 5, 10291031.

(6) a) Köpf-Maier, P.; Köpf, H.; Neuse, E. W. J. Cancer Res. Clin. Oncol. 1984, 108, 336-340; b) Köpf-Maier, P.; Köpf, H. Chem. Rev. 1987, 87, 1137-1152; c) van Staveren, D. R.; Metzler-Nolte, N. Chem. Rev. 2004, 104, 5931-5986; d) Goldstein, S.; Meyerstein, D.; Czapski, G. Free Radicals Biol. Med. 1993, 15, 435-445.

(7) a) Halliwell, B. Biochem. J. 2007, 401, 1-11; b) Engel, R. H.; Evens, A. W. Front. Biosci. 2006, 11, 300-312; c) Finkel, T. Curr. Opin. Cell Biol. 2003, 15, 247-254; d) Schumacker, P. T. Cancer Cell. 2006, 10, 175-176; e) O'Donnell-Tormey, J.; DeBoer, C. J.; Nathan, C. F. J. Clin. Invest. 1985, 76, 80-86; f) Szatrowski, T. P.; Nathan, C. F. Cancer Res. 1991, 51, 794-798; g) Stone, J. R. Arch. Biochem. Biophys. 2004, 422, 119-124; h) Antunes, F.; Cadenas, E. FEBS Lett. 2000, 475, 121-126.

(8) a) Lilienthal, N.; Prinz, C.; Peer-Zada, A. A.; Doering, M.; Ba, L. A.; Hallek, M.; Jacob, C.; Herling, M. Leuk. Lymphoma. 2011, 52, 1407-1411; b) Doering, M.; Ba, L. A.; Lilienthal, N.; Nicco, C.; Scherer, C.; Abbas, M.; Zada, Abdul Ali Peer; Coriat, R.; Burkholz, T.; Wessjohann, L.; Diederich, M.; Batteux, F.; Herling, M.; Jacob, C. J. Med. Chem. 2010, 53, 6954-6963.

(9) a) Dolmans, D. E. J. G. J.; Fukumura, D.; Jain, R. K. Nat. Rev. Cancer. 2003, 3, 380-387; b) Taub, A. F. Dermantol. Clin. 2007, 25, 101-109; c) Vera, D. M. A.; Haynes, M. H.; Ball, A. R.; Dai, T.; Astrakas, C.; Kelso, M. J.; Hamblin, M. R.; Tegos, G. P. Photochem. Photobiol. 2012, 88, 499-511.

(10) a) Mayer, G.; Heckel, A. Angew. Chem. Int. Ed. 2006, 45, 4900-4921; b) McCoy, C. P.; Rooney, C.; Edwards, C. R.; Jones, D. S.; Gorman, S. P. J. Am. Chem. Soc. 2007, 129, 9572-9573; c) Wei, Y.; Yan, Y.; Pei, D.; Gong, B. Bioorg. Med. Chem. Lett. 1998, 8, 2419 2422; d) Ibsen, S.; Zahavy, E.; Wrasdilo, W.; Berns, M.; Chan, M.; Esener, S. Pharm. Res. 2010, 27, 1848-1860; e) Kehayova, P. D.; Woodrell, C. D.; Dostal, P. J.; Chandra, P. P.; Jain, A. Photochem. Photobiol. Sci. 2002, 1, 774-779; f) Noguchi, M.; Skwarczynski, M.; Prakash, H.; Hirota, S.; Kimura, T.; Hayashi, Y.; Kiso, Y. Bioorg. Med. Chem. 2008, 16, 5389-5397; g) Lin, W.; Peng, D.; Wang, B.; Long, L.; Guo, C.; Yuan, J. Eur. J. Org. Chem. 2008, 2008, 793-796; h) Ueberschaar, N.; Dahse, H.-M.; Bretschneider, T.; Hertweck, C. Angew. Chem. Int. Ed. 2013, 52, 6185-6189. 
(11) Goeldner, M.; Givens, R., Eds. Dynamic studies in biology: Phototriggers, photoswitches and caged biomolecules; Wiley-VCH: Weinheim, 2005.

(12) a) Roy, M.; Saha, S.; Patra, A. K.; Nethaji, M.; Chakravarty, A. R. Inorg. Chem. 2007, 46, 4368-4370; b) Farrer, N. J.; Woods, J. A.; Salassa, L.; Zhao, Y.; Robinson, K. S.; Clarkson, G.; Mackay, F. S.; Sadler, P. J. Angew. Chem. Int. Ed. 2010, 49, 8905-8908; c) Maeda, D.; Shimakoshi, H.; Abe, M.; Hisaeda, Y. Dalton Trans. 2009, 140-145; d) Westendorf, A. F.; Woods, J. A.; Korpis, K.; Farrer, N. J.; Salassa, L.; Robinson, K.; Appleyard, V.; Murray, K.; Grünert, R.; Thompson, A. M.; Sadler, P. J.; Bednarski, P. J. Mol. Cancer Ther. 2012, 11, 1894-1904; e) Maldonado, C. R.; Gomez-Blanco, N.; JaureguiOsoro, M.; Brunton, V. G.; Yate, L.; Mareque-Rivas, J. C. Chem. Commun. 2013, 49, 39853987; f) Butler, J. S.; Sadler, P. J. Curr. Opin. Chem. Biol. 2013, 17, 175-188; g) Mlcouskova, J.; Stepankova, J.; Brabec, V. J. Biol. Inorg. Chem. 2012, 17, 891-898; h) Zhao, Y.; Roberts, G. M.; Greenough, S. E.; Farrer, N. J.; Paterson, M. J.; Powell, W. H.; Stavros, V. G.; Sadler, P. J. Angew. Chem. Int. Ed. 2012, n/a; i) Talib, J.; Harman, D. G.; Dillon, C. T.; Aldrich-Wright, J.; Beck, J. L.; Ralph, S. F. Dalton Trans. 2009, 504-513; j) Patra, A. K.; Bhowmick, T.; Roy, S.; Ramakumar, S.; Chakravarty, A. R. Inorg. Chem. 2009, 48, 2932-2943; k) Goswami, T. K.; Roy, M.; Nethaji, M.; Chakravarty, A. R.

Organometallics. 2009, 28, 1992-1994; I) Barragán, F.; López-Senín, P.; Salassa, L.; Betanzos-Lara, S.; Habtemariam, A.; Moreno, V.; Sadler, P. J.; Marchán, V. J. Am. Chem. Soc. 2011, 133, 14098-14108; m) Howerton, B. S.; Heidary, D. K.; Glazer, E. C. J. Am. Chem. Soc. 2012, 134, 8324-8327; n) Wachter, E.; Heidary, D. K.; Howerton, B. S.; Parkin, S.; Glazer, E. C. Chem. Commun. 2012, 48, 9649-9651; o) Frasconi, M.; Liu, Z.; Lei, J.; Wu, Y.; Strekalova, E.; Malin, D.; Ambrogio, M. W.; Chen, X.; Botros, Y. Y.; Cryns, V. L.; Sauvage, J.-P.; Stoddart, J. Fraser. J. Am. Chem. Soc. 2013, 135, 11603-11613; p) Hussain, A.; Gadadhar, S.; Goswami, T. K.; Karande, A. A.; Chakravarty, A. R. Dalton Trans. 2012, 41, 885-895; q) Kastl, A.; Wilbuer, A.; Merkel, A. L.; Feng, L.; Di Fazio, P.; Ocker, M.; Meggers, E. Chem. Commun. 2012, 48, 1863-1865; r) Zhou, Q.-X.; Lei, W.-H.; Hou, Y.-J.; Chen, Y.-J.; Li, C.; Zhang, B.-W.; Wang, X.-S. Dalton Trans. 2013, 42, 27862791; s) Butler, J. S.; Woods, J. A.; Farrer, N. J.; Newton, M. E.; Sadler, P. J. J. Am. Chem. Soc. 2012, 134, 16508-16511.

(13) a) Zayat, L.; Calero, C.; Alborés, P.; Baraldo, L.; Etchenique, R. J. Am. Chem. Soc. 2003, 125, 882-883; b) Zayat, L.; Salierno, M.; Etchenique, R. Inorg. Chem. 2006, 45, 1728-1731; c) Zayat, L.; Noval, M. G.; Campi, J.; Calero, C. I.; Calvo, D. J.; Etchenique, R. ChemBioChem. 2007, 8, 2035-2038; d) Salierno, M.; Fameli, C.; Etchenique, R. Eur. J. Inorg. Chem. 2008, 2008, 1125-1128; e) Respondek, T.; Garner, R. N.; Herroon, M. K.; Podgorski, I.; Turro, C.; Kodanko, J. J. J. Am. Chem. Soc. 2011, 133, 17164-17167.

(14) a) Ciesienski, K. L.; Haas, K. L.; Dickens, M. G.; Tesema, Y. T.; Franz, K. J. J. Am. Chem. Soc. 2008, 130, 12246-12247; b) Ciesienski, K. L.; Hyman, L. M.; Yang, D. T.; Haas, K. L.; Dickens, M. G.; Holbrook, R. J.; Franz, K. J. Eur. J. Inorg. Chem. 2010, 2224-2228; c) Kumbhar, A. A.; Franks, A. T.; Butcher, R. J.; Franz, K. J. Chem. Commun. 2013, 49, 2460 2462; d) Joshi, T.; Pierroz, V.; Mari, C.; Gemperle, L.; Ferrari, S.; Gasser, G. Angew. Chem. Int. Ed. 2014, 53, 2960-2963; e) Joshi, T.; Gasser, G. Synlett. 2015, 26, 275-284; f) Mari, C.; Pierroz, V.; Ferrari, S.; Gasser, G. Chem. Sci. 2015, 6, 2660-2686.

(15) Leonidova, A.; Pierroz, V.; Rubbiani, R.; Lan, Y.; Schmitz, A. G.; Kaech, A.; Sigel, R. K. O.; Ferrari, S.; Gasser, G. Chem. Sci. 2014, 4044-4056.

(16) Figueira, T. R.; Barros, M. H.; Camargo, A. A.; Castilho, R. F.; Ferreira, Julio C B; Kowaltowski, A. J.; Sluse, F. E.; Souza-Pinto, N. C.; Vercesi, A. E. Antioxid. Redox Signaling. 2013, 18, 2029-2074. 
(17) Tang, X.; Dmochowski, I. J. Nat. Protocols. 2007, 1, 3041-3048.

(18) Leonidova, A.; Pierroz, V.; Adams, L. A.; Barlow, N.; Ferrari, S.; Graham, B.; Gasser, G. ACS Med. Chem. Lett. 2014, 5, 809-814.

(19) Mari, C.; Pierroz, V.; Leonidova, A.; Ferrari, S.; Gasser, G. Eur. J. Inorg. Chem., 2015, 3879-3891.

(20) Heinze, K.; Schlenker, M. Eur. J. Inorg. Chem. 2004, 2974-2988.

(21) Gug, S.; Charon, S.; Specht, A.; Alarcon, K.; Ogden, D.; Zietz, B.; Léonard, J.;

Haacke, S.; Bolze, F.; Nicoud, J.-F.; Goeldner, M. ChemBioChem. 2008, 9, 1303-1307.

(22) Anstaett, P.; Pierroz, V.; Ferrari, S.; Gasser, G. Photochem. Photobiol. Sci. 2015, DOI: 10.1039/C5PP00245A.

(23) Corrie, J. E. T.; Reid, G. P.; Trentham, D. R.; Hursthouse, M. B.; Mazid, M. A. J. Chem. Soc., Perkin Trans. 1. 1992, 1015-1019.

(24) Martina, S.; MacDonald, S. A.; Enkelmann, V. J. Org. Chem. 1994, 59, 3281-3283.

(25) a) Marugan, J. J.; Leonard, K.; Raboisson, P.; Gushue, J. M.; Calvo, R.; Koblish, H.

K.; Lattanze, J.; Zhao, S.; Cummings, M. D.; Player, M. R.; Schubert, C.; Maroney, A. C.; Lu, T. Bioorg. Med. Chem. Lett. 2006, 16, 3115-3120; b) Stupi, B. P.; Li, H.; Wang, J.; Wu, W.; Morris, S. E.; Litosh, V. A.; Muniz, J.; Hersh, M. N.; Metzker, M. L. Angew. Chem. Int. Ed. 2012, 51, 1724-1727.

(26) Anstaett, P.; Leonidova, A.; Gasser, G. ChemPhysChem. 2015, 16, 1857-1860.

(27) Corrie, J. E. T.; Kaplan, J. H.; Forbush, B.; Ogden, D. C.; Trentham, D. R. ChemPhysChem. 2015, 16, 1861-1862.

(28) Anstaett, P.; Leonidova, A.; Janett, E.; Bochet, C. G.; Gasser, G. ChemPhysChem. 2015, 16, 1863-1866.

(29) Gray, H. B.; Sohn, Y. S.; Hendrickson, N. J. Am. Chem. Soc. 1971, 93, 3603-3612.

(30) Burdette, S. C. Eur. J. Inorg. Chem. 2015, DOI: 10.1002/ejic.201500566.

(31) a) Boca, S. C.; Four, M.; Bonne, A.; van der Sanden, Boudewijn; Astilean, S.;

Baldeck, P. L.; Lemercier, G. Chem. Commun. 2009, 4590-4592; b) Araya, R.; Andino-

Pavlovsky, V.; Yuste, R.; Etchenique, R. ACS Chem. Neurosci. 2013, 4, 1163-1167; c)

Zayat, L.; Filevich, O.; Baraldo, L. M.; Etchenique, R. Phil. Trans. R. Soc. A. 2013, 371.

(32) Leonidova, A.; Joshi, T.; Nipkow, D.; Frei, A.; Penner, J.-E.; Konatschnig, S.; Patra, M.; Gasser, G. Organometallics. 2013, 32, 2037-2040.

(33) Leonidova, A.; Pierroz, V.; Rubbiani, R.; Heier, J.; Ferrari, S.; Gasser, G. Dalton Trans. 2014, 43, 4287-4294.

(34) Spingler, B.; Schnidrig, S.; Todorova, T.; Wild, F. CrystEngComm. 2012, 14, 751.

(35) CrysAlis ${ }^{\text {Pro }}$ Software System; Oxford Diffraction Ldt.: Oxford, UK, 2007.

(36) Altomare, A.; Burla, M. C.; Camalli, M.; Cascarano, G. L.; Giacovazzo, C.;

Guagliardi, A.; Moliterni, Anna Grazia Giuseppina; Polidori, G.; Spagna, R. J. Appl. Cryst. 1999, 32, 115-119.

(37) Sheldrick, G. Acta Cryst. 2008, A64, 112-122. 


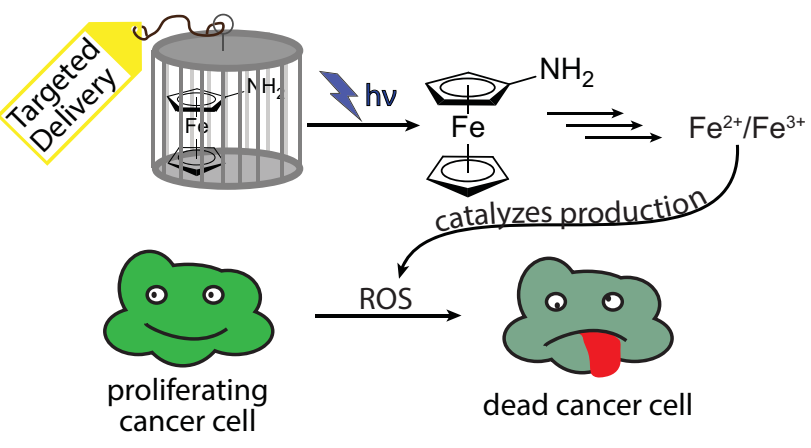

Synopsis: In this article, the selective photo-release in living cells of a cytotoxic organometallic complex, namely aminoferrocene $\left(\mathbf{F c}-\mathbf{N H}_{2}\right)$ from two different bioconjugates containing a mitochondria targeting peptide (MLS) is presented. 